\title{
Livin serves as a prognostic marker for mid-distal rectal cancer and a target of mid-distal rectal cancer treatment
}

\author{
QI-BIAO SU ${ }^{1}$, LAI-YOU WANG ${ }^{2}$, GUI-NING WEI ${ }^{3}$, LI-ZHEN LIAO $^{1}$, JIE ZHAO $^{1}$, \\ HONG-JUN LIU ${ }^{3}$, YU-LONG SHI ${ }^{4}$, LE-PING $\mathrm{LI}^{4}$ and CHEN-SHENG $\mathrm{LI}^{4}$ \\ ${ }^{1}$ College of Health Science; ${ }^{2}$ College of Pharmacy, Guangdong Pharmaceutical University, \\ Guangzhou, Guangdong 510006; ${ }^{3}$ Department of Pharmacology, Guangxi Institute of Chinese Medicine \\ and Pharmaceutical Science, Nanning, Guangxi 530022; ${ }^{4}$ Department of Gastrointestinal Surgery, \\ Shandong Provincial Hospital Affiliated to Shandong University, Jinan, Shandong 250021, P.R. China
}

Received June 14, 2016; Accepted August 23, 2017

DOI: $10.3892 / 01.2017 .7230$

\begin{abstract}
Livin is a novel member of the inhibitor of apoptosis protein family, which has been identified to be expressed in various malignancies and is suggested to be associated with poor prognostic significance. However, no data are available concerning the significance of livin in mid-distal rectal cancer. In the present study, livin expression, and its association with clinicopathological characteristics and prognosis was examined in patients with mid-distal rectal cancer. Apoptotic susceptibility, invasion capacity and chemosensitivity of LoVo cells were investigated using small interfering RNA (siRNA)-mediated knockdown of livin. It was revealed that livin was highly expressed in mid-distal rectal cancer tissues compared with the normal rectal mucosal tissues. Livin expression was associated with pathological grade, extent of invasion (T stage) and extent of lymph node metastasis ( $\mathrm{N}$ stage) of tumor, contributing to poor prognosis of mid-distal rectal cancer following surgery. The data suggest that aggressive surgery should be applied in patients with mid-distal rectal cancer with high expression of livin. It was also revealed that knockdown of livin by siRNA increased the apoptotic rate, suppressed invasion of LoVo cells, and decreased the half-maximal inhibitory concentration of oxaliplatin and 5 -fluorouracil by $\sim 50 \%$ in LoVo cells significantly compared with control groups. The data suggested that a combination of downregulation of livin and anticancer drugs may significantly decrease the toxicity of anticancer drugs. Taken together, the present study indicated that livin may be a promising target in clinical therapy of mid-distal rectal cancer.
\end{abstract}

Correspondence to: Dr Chen-Sheng Li, Department of Gastrointestinal Surgery, Shandong Provincial Hospital Affiliated to Shandong University, 324 Jingwu Road, Jinan, Shandong 250021, P.R. China

E-mail: chensheng76@163.com

Key words: livin, mid-distal rectal cancer, prognosis, apoptosis, invasion, chemosensitivity

\section{Introduction}

Colorectal cancer (CRC) is the third most common type of cancer in males, the second in females worldwide, and the fourth most common cause of cancer-associated mortality following lung, stomach and liver cancer (1).

High incidence rates are usually observed in the Western world, but during the past few decades, China has experienced an increase in the incidence of rectal cancer (2). CRC is a heterogeneous disease, particularly with respect to the ethnicity of patients, tumor stage and genetic alterations that contribute to its progression (3). Surgery, chemotherapy and radiotherapy are the traditional main treatments for rectal cancer (4). The majority of patients with rectal cancer are already at the advanced stage when they are diagnosed, which often leads to poor outcomes following surgery, thus, identification of key regulators governing the progression and malignant behavior of rectal cancer may aid in evaluating the patient prognosis, and provide targets for cancer prevention or therapy $(5,6)$.

As is known, inhibition of apoptosis performs an important role in oncogenesis, which is mediated by a group of inhibitors of apoptosis proteins (IAPs) $(7,8)$. Various studies demonstrated that overexpression of IAP facilitates the accumulation and survival of tumor cells, and improves tumor drug resistance to antitumor drugs $(9,10)$. To date, identified IAPs comprise eight members in human cells, including insulin-like peptide (ILP)-1, cellular (c)-IAP1 (HIAP-2), c-IAP2 (HIAP-1), neuronal apoptosis inhibitory protein, Survivin, BRUCE (apollon), livin (ML-IAP, KIAP) and ILP-2 (11). Livin was originally identified in melanoma and is expressed in several types of malignant tumors, including bladder cancer, lung cancer, breast carcinoma, acute lymphoblastic leukemia and gastric cancer (12-16).

Although Korean (17) and Chinese (18) scientists reported the association of livin with colorectal cancer progression, in regard to the fact that mid-distal rectal cancer comprise $70-80 \%$ of rectal cancer in China (19), and to a certain extent, the effect of surgery for mid-distal cancer is attenuated by the anatomy constraint of narrow pelvis. Furthermore, thus far, there are no studies that have evaluated the role of livin in mid-distal rectal cancer. To the best of our knowledge, 
the present study examined for the first time livin expression in human mid-distal rectal cancer tissues, evaluated the association between its expression and clinicopathological characteristics and prognosis. In addition, this study investigated the effects of livin on apoptotic susceptibility, invasion capability and the chemosensitivity of LoVo cells. The present data indicated that livin contributes to the aggressive behavior of human mid-distal rectal cancer and may serve as a potential target for mid-distal rectal cancer therapy.

\section{Materials and methods}

Patients. A total of 180 patients with mid-distal rectal cancer (median age, 58 years old; age range, $40-76$ years old), including 117 tubular adenocarcinomas and 63 mucinous adenocarcinomas receiving total mesorectal excision were enrolled in the present study. All tumor specimens were obtained from patients operated on at Shandong Provincial Hospital Affiliated to Shandong University (Shandong, China) between May 2001 and October 2005. Written informed consent was obtained from all 180 patients. Each tumor was assigned a histological type according to the Chinese Classification of Rectal Carcinoma, which abides by the World Health Organization classification of malignant tumors (20), and infiltration was graded according to the International Union against Cancer TNM Classification of Malignant Tumors (21). The study obtained ethical approval from the Research Ethics Committee of Shandong Provincial Hospital Affiliated to Shandong University and observed the Helsinki Declaration. In total, 72 tumors were stage I-II, 108 were stage III-IV and 76 were at the lymph node metastasis stage. The corresponding normal rectal mucosal tissues $(5 \mathrm{~cm}$ away from the tumor edge) were evaluated as normal controls. Diagnosis was performed by two independent pathologists, and those cases with questionable diagnosis were omitted from the present study. All the patients enrolled were followed up post-surgery by telephone, letter or re-examination in the outpatient department, with a median follow-up time of 71 months. No cases treated by radiotherapy and/or chemotherapy were included.

Immunohistochemistry. Samples sections were fixed with $10 \%$ neutral buffered formalin for $24 \mathrm{~h}$ at $4^{\circ} \mathrm{C}$, dehydrated in graded ethanol $(50,70,80,90,95$ and $100 \%)$ and embedded in paraffin. Paraffin sections $(4 \mu \mathrm{m})$ were deparaffinized and rehydrated in graded ethanol $(100,95,80,70$ and 50\%). Heat-mediated antigen retrieval was performed using a pressure cooker treatment for $10 \mathrm{~min}$ in the citrate buffer $\left(\mathrm{pH} \mathrm{6.0)}\right.$ at $100^{\circ} \mathrm{C}$. Endogenous peroxide activity was quenched by hydrogen peroxide (3\%) for $10 \mathrm{~min}$ at room temperature. The slides were incubated overnight at $4{ }^{\circ} \mathrm{C}$ with a primary antibody for livin (rabbit polyclonal livin antibody; catalog no. ab97350; dilution, 1:100; Abcam, Cambridge, MA, USA) and with a horseradish peroxidase-labeled dextran polymer-conjugated goat anti-rabbit antibody (catalog no. K4003; dilution, 1:100; Dako; Agilent Technologies, Inc., Santa Clara, CA, USA) for $30 \mathrm{~min}$ at $37^{\circ} \mathrm{C}$ subsequent to washing with TBS (pH 7.4). Negative controls were processed in the absence of primary antibody. The reaction products were viewed using diaminobenzidine and hematoxylin staining at room temperature for $5 \mathrm{~min}$. Livin expression levels were classified into two categories depending on the percentage of cells stained. The mean percentage of positive tumor cells for the expression of livin was determined in at least five areas at 200-fold magnification under a light microscope, and cases with $<10 \%$ positively stained tumor cells were defined as negative, while the remainder were defined as positive.

Cell culture and small interfering RNA (siRNA) transfection. CRC LoVo cells were obtained from the Cell Bank of the Type Culture Collection of Chinese Academy of Sciences (Shanghai, China). Cells were grown in Dulbecco's modified Eagle's medium (Thermo Fisher Scientific Inc., Waltham, MA, USA) with $10 \%$ fetal bovine serum (FBS; Thermo Fisher Scientific Inc.), penicillin (100 U/ml) and streptomycin $(100 \mu \mathrm{g} / \mathrm{ml})$ in a humidified atmosphere at $37^{\circ} \mathrm{C}$ with $5 \% \mathrm{CO}_{2}$. Cells were periodically detached with $0.25 \%$ trypsin-ethylene diamine tetraacetic acid solution and subsequently replated. Cells in the logarithmic phase were used for the experiments. Livin was knocked down with siRNA against livin (Invitrogen; Thermo Fisher Scientific, Inc.) according to the manufacturer's protocol. Duplex sequences of siRNA-livin were as follows: a-GGAGUUGCGUCUGGGCUCCUCUAU and b-AUAGAA GGAAGGCCAGACGCAACUCC. The transfection mixture consisted of antibiotic-free culture medium and $100 \mathrm{nM}$ siRNA. The non-targeting scrambled siRNA (Invitrogen; Thermo Fisher Scientific, Inc.) was used as a negative control. Following siRNA transfection according to the manufacturer's protocol, the cells were incubated and then used for various analyses.

Reverse-transcription-quantitative polymerase chain reaction $(R T-q P C R)$ analysis. Total RNA was extracted from cells $48 \mathrm{~h}$ post-transfection using TRIzol reagent (Invitrogen; Thermo Fisher Scientific, Inc.) according to the manufacturer's protocol. Reverse transcription was performed using a one-step RT-polymerase chain reaction (PCR) kit (Thermo Fisher Scientific, Inc.). The reaction conditions were as follows: $37^{\circ} \mathrm{C}$ for $15 \mathrm{~min}$ and $85^{\circ} \mathrm{C}$ for $5 \mathrm{sec}$ and then the mix was stored at $4^{\circ} \mathrm{C}$. PCR reactions were undertaken using the Real-time PCR Master Mix (SYBR-Green) reagent kit (Toyobo Life Science, Osaka, Japan), according to the manufacturer's protocol. PCR was run in $20 \mu \mathrm{l}$ total volume. Primer sequences were: $\beta$-actin forward, 5'-AGTGTGACG TTGACATCCGT-3' and reverse, 5'-TGCTAGGAGCCA GAGCAGTA-3'; livin forward, 5'-CGGCCCCTGACAGAG GAGGA-3' and reverse, 5'-AGGCCAGACGCAACTCCT CA-3' (22). The PCR was performed by initial incubation at $95^{\circ} \mathrm{C}$ for $5 \mathrm{~min}$ followed by 30 cycles of denaturation at $95^{\circ} \mathrm{C}$ for $15 \mathrm{sec}$, annealing at $60^{\circ} \mathrm{C}$ for $15 \mathrm{sec}$ and extension at $72^{\circ} \mathrm{C}$ for $45 \mathrm{sec}$. Livin mRNA quantification was performed by the $2^{-\Delta \Delta \mathrm{Cq}}$ method (23).

Western blot analysis. At $48 \mathrm{~h}$ post-transfection, cells were collected, lysed in an ice-cold lysis buffer containing $150 \mathrm{mM}$ $\mathrm{NaCl}, 50$ mM Tris- $\mathrm{HCl}$ (pH 8.0), 0.1\% SDS, 1\% Nonidet P-40 and a protease inhibitor cocktail (Boehringer, Mannheim, Germany). Lysates were centrifuged at 100,000 x g for $30 \mathrm{~min}$ at $4^{\circ} \mathrm{C}$ and supernatants were collected. Protein concentrations were determined using the Bio-Rad protein determination method (Bio-Rad Laboratories, Inc., Hercules, CA, USA). 
An aliquot of each sample equivalent to $100 \mu \mathrm{g}$ protein was boiled in sample buffer, separated on a 8-12\% SDS-PAGE, and then transferred to polyvinylidene difluoride membranes. The membranes were blocked with $5 \%$ non-fat milk at room temperature for $1 \mathrm{~h}$, washed with TBST (50 mM Tris, $300 \mathrm{mM}$ $\mathrm{NaCl} \mathrm{pH} 7.6,0.1 \%$ Tween) and incubated with the primary antibody (livin antibody; catalog no. 2505; dilution, 1:500; housekeeping gene $\beta$-actin monoclonal antibody; catalog no. 3777; dilution, 1:5,000; ProSCI, Inc., Poway, CA, USA) at $4^{\circ} \mathrm{C}$ overnight. Blots were then washed with TBST $(50 \mathrm{mM}$ Tris, $300 \mathrm{mM} \mathrm{NaCl} \mathrm{pH} \mathrm{7.6,0.1 \%} \mathrm{Tween)} \mathrm{and} \mathrm{incubated} \mathrm{with}$ peroxidase-linked secondary antibodies (catalog No. 97100, dilution 1:5000, Abcam, Inc., Cambridge, MA, USA) at $37^{\circ} \mathrm{C}$ for $1 \mathrm{~h}$. Bound antibodies were developed using the Super Enhanced Chemiluminescence plus detection reagent (Applygen Technologies, Inc., Beijing, China). Densitometric analysis was performed using GDS-8000 UVP photo scanner (Bio-Rad Laoratories, Inc.) and Quantity one 4.2.2 software (Bio-Rad Laboratories, Inc.). Cells transfected with siRNAs that had the highest downregulation rates of livin were selected for the subsequent assays.

Analysis of cell apoptosis. At $48 \mathrm{~h}$ post-transfection, LoVo cells on plates were harvested by trypsin-EDTA (Invitrogen; Thermo Fisher Scientific, Inc.); cells were washed with ice-cold PBS and incubated with $500 \mu 1$ of the annexin $\mathrm{V}$-binding buffer at room temperature for $5 \mathrm{~min}$. Annexin V-fluorescein isothiocyanate $(5 \mu \mathrm{l})$ and $10 \mu \mathrm{l}$ of PI were added to each cell suspension, and incubated at room temperature for $10 \mathrm{~min}$ in the dark prior to analysis by flow cytometry (BD Biosciences, San Jose, CA, USA). The apoptotic rate was determined using CellQuest software (version 5.1; BD Biosciences).

Cell invasion assay. Invasion of LoVo cells was measured using Transwell cell culture chambers ( $8 \mu \mathrm{m}$ pore size) containing a Matrigel-coated polycarbonate membrane filter. Cells $\left(1 \times 10^{4}\right.$ cells/well) in $500 \mu$ l of serum-free RPMI-1640 (Invitrogen; Thermo Fisher Scientific, Inc.) were placed in the upper chamber of the Transwell insert, and the lower chamber was filled with $750 \mu$ l culture medium with $10 \%$ FBS. Following incubation at $37^{\circ} \mathrm{C}$ for $24 \mathrm{~h}$, non-invasive cells on the upper surface of the filter were removed using a cotton swab, and the invasive cells on the bottom side of the membrane were stained with hematoxylin and eosin at room temperature for $10 \mathrm{~min}$. The number of cells was counted under a light microscope from six random fields (magnification, $\mathrm{x} 200$ ). The experiment was repeated three times.

Chemosensitivity assay. LoVo cells were treated with a concentration gradient of anticancer drugs prior to and following livin gene knockdown. The anticancer drugs, oxaliplatin (L-OHP) and 5-flourouracil (5-FU), both purchased from Bristol-Myers Squibb (Princeton, NJ, USA), were tested in six dilutions corresponding to $200,100,50,25,12.5$, and $6.25 \%$ of each drug standard test drug concentration (TDC; $100 \%$ TDC used as follows: L-OHP $16 \mu \mathrm{M}, 5-\mathrm{FU} 8 \mu \mathrm{M})$. The cells were seeded at a density of $3 \times 10^{4}$ cells/well on 96 -well plates in RPMI-1640 medium, each well was repeated in triplicate. Following incubation overnight at $37^{\circ} \mathrm{C}$, the medium

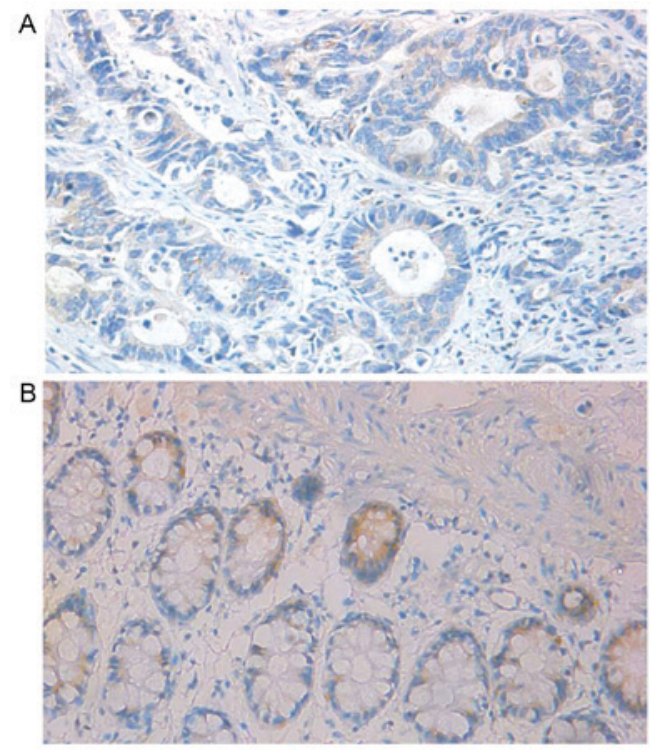

Figure 1. Livin protein expression in mid-distal rectal cancer tissues and normal rectal mucosal tissues by immunohistochemistry. (A) Livin protein was strongly immunostained in mid-distal rectal cancer tissues (magnification, $\mathrm{x} 200$ ). (B) Livin protein was weakly immunostained in normal rectal mucosal tissues (magnification, $\mathrm{x} 200$ ).

was replaced by fresh medium containing the test drug. All the cells were treated for $48 \mathrm{~h}$. At the end of the treatment, cell viability was determined colorimetrically using Cell Counting Kit-8 (Dojindo Molecular Technologies, Inc., Kumamoto, Japan). Following incubation for $2 \mathrm{~h}$, the 96 -well plate was scanned by an ELISA reader at $450 \mathrm{~nm}$ for optical density values to calculate the percentage of cell inhibition and half-maximal inhibitory concentration $\left(\mathrm{IC}_{50}\right)$ (inhibitory concentration to achieve $50 \%$ cell death).

Statistical analysis. All data were analyzed by SPSS 16.0 statistical software (SPSS, Inc., Chicago, IL, USA). Each assay was performed at least 3 times. The data were expressed as mean \pm standard deviation. The expression of livin was analyzed by the $\chi^{2}$ test. Recurrence-free survival curves were constructed using the Kaplan-Meier method and life tables, and were compared using the log-lank test. The prognostic indicators of livin expression for recurrence were assessed using the Cox proportional hazards model. $\mathrm{P}<0.05$ was considered to indicate a statistically significant difference.

\section{Results}

Expression of livin in mid-to-distal rectal cancer tissues. Among 180 cases of cancer, 96 cases (53.33\%) exhibited positive staining for livin, whereas out of 30 control cases, only 2 cases $(6.67 \%)$ exhibited positive staining (Fig. 1). There was a significant difference in the positive staining rate between the mid-to-distal rectal cancer and the control group $\left(\chi^{2}=22.50\right.$; $\mathrm{P}<0.01)$. Livin expression was associated with the known prognostic variables, including pathology stage, $\mathrm{T}$ stage and lymph node metastasis (all $\mathrm{P}<0.05$; Table I), but not with age, sexuality, blood transfusion, course of disease, and tumor size (all P>0.05; Table I). A significant difference in the 5-year survival rate between patients with positive and negative 
Table I. Association between livin expression and the clinicopathological features of patients with mid-distal rectal cancer.

\begin{tabular}{|c|c|c|c|c|c|c|}
\hline \multirow[b]{2}{*}{ Characteristic } & \multirow[b]{2}{*}{ Number of cases } & \multicolumn{3}{|c|}{ Livin } & \multirow[b]{2}{*}{$\chi^{2}$} & \multirow[b]{2}{*}{ P-value } \\
\hline & & - & + & Positive ratio & & \\
\hline \multicolumn{7}{|l|}{ Gender } \\
\hline Male & 105 & 51 & 54 & 0.51 & \multirow[t]{2}{*}{0.37} & \multirow[t]{2}{*}{0.54} \\
\hline Female & 75 & 33 & 42 & 0.54 & & \\
\hline \multicolumn{7}{|l|}{ Age, years } \\
\hline$\leq 50$ & 66 & 30 & 36 & 0.55 & \multirow{2}{*}{0.06} & \multirow[t]{2}{*}{0.80} \\
\hline$>50$ & 104 & 54 & 60 & 0.58 & & \\
\hline \multicolumn{7}{|l|}{ Blood transfusion } \\
\hline Yes & 116 & 55 & 61 & 0.53 & \multirow[t]{2}{*}{0.07} & \multirow[t]{2}{*}{0.79} \\
\hline No & 64 & 29 & 35 & 0.55 & & \\
\hline \multicolumn{7}{|l|}{ Course, months } \\
\hline$\leq 6$ & 116 & 49 & 67 & 0.58 & \multirow[t]{2}{*}{2.57} & \multirow{2}{*}{0.11} \\
\hline$>6$ & 64 & 35 & 29 & 0.45 & & \\
\hline \multicolumn{7}{|l|}{ Tumor size, cm } \\
\hline$\leq 5$ & 93 & 48 & 45 & 0.48 & \multirow[t]{2}{*}{1.89} & \multirow[t]{2}{*}{0.17} \\
\hline$>5$ & 87 & 36 & 51 & 0.59 & & \\
\hline \multicolumn{7}{|l|}{ Pathology stage } \\
\hline Adenocarcinoma & 117 & 62 & 55 & 0.47 & \multirow[t]{2}{*}{5.37} & \multirow[t]{2}{*}{0.02} \\
\hline Mucinous adenocarcinoma & & & & & & \\
\hline Signet ring cell carcinoma & 63 & 22 & 41 & 0.65 & & \\
\hline \multicolumn{7}{|l|}{ Depth of invasion } \\
\hline $\mathrm{T}_{1}+\mathrm{T}_{2}$ & 72 & 58 & 14 & 0.19 & \multirow[t]{2}{*}{55.37} & \multirow[t]{2}{*}{$<0.01$} \\
\hline $\mathrm{T}_{3}+\mathrm{T}_{4}$ & 108 & 26 & 82 & 0.76 & & \\
\hline \multicolumn{7}{|l|}{ Lymph node metastasis } \\
\hline Yes & 114 & 56 & 48 & 0.42 & \multirow[t]{2}{*}{5.10} & \multirow[t]{2}{*}{0.02} \\
\hline No & 76 & 28 & 48 & 0.63 & & \\
\hline
\end{tabular}

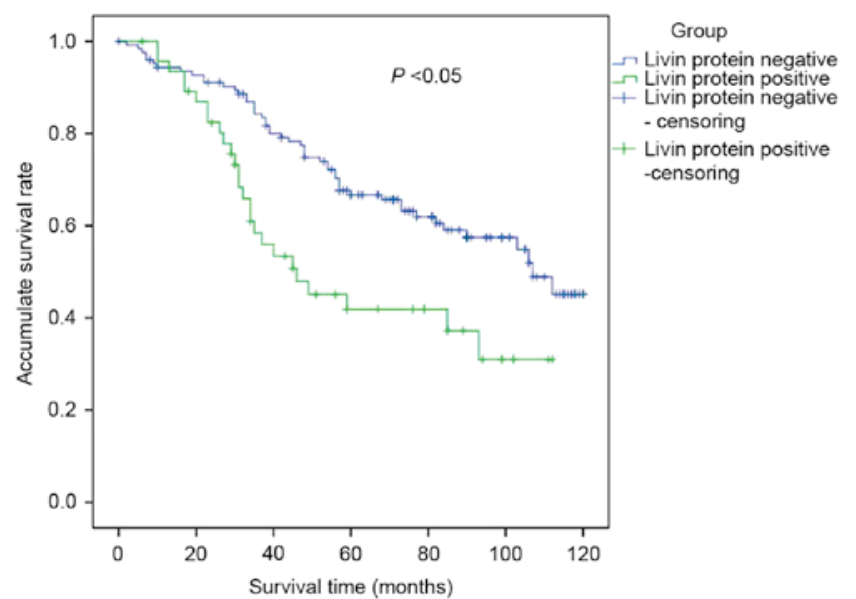

Figure 2. Kaplan-Meier analysis. The 5-year survival rate of patients with positive livin expression was lower compared with that of patients with negative livin expression (45 vs. $68 \%$; $\mathrm{P}<0.05$ ).

expression of livin was observed (45 vs. $68 \%$; P<0.05, Fig. 2). Univariate analysis in the Cox regression model revealed that 5-year survival rate was associated with pathology stage, $\mathrm{T}$ stage, lymph node metastasis and livin expression $(\mathrm{P}<0.05$;
Table II), but not with age, sexuality, blood transfusion, course of disease, and tumor size ( $\mathrm{P}>0.05$; Table II). Multivariate Cox regression analysis confirmed an independent and significant effect of livin expression, and lymph node metastasis on the prognosis of patients $(\mathrm{P}<0.05$; Table III).

Stable knockdown of livin by siRNA in LoVo cells. Expression of livin protein in LoVo cells was examined by western blot analysis (data not shown). To characterize the biological role of livin in mid-to-distal rectal cancer, a specific siRNA was employed for livin to knockdown livin expression in LoVo cells expressing the highest level of endogenous livin. Stable transformants were identified using RT-qPCR and western blot analysis. The results showed that the livin mRNA and protein levels in cells transfected with specific siRNA for livin were significantly reduced compared with those transfected with control siRNA (both $\mathrm{P}<0.05$; Fig. 3).

Knockdown of livin promotes LoVo cell apoptosis. To detect whether livin siRNA was able to induce apoptosis of LoVo cells, at $48 \mathrm{~h}$ after infection of livin siRNA, control siRNA or PBS, the cell apoptotic rate was detected by flow cytometry. Apoptotic cells were determined by annexin V-positive and PI-negative cells. The results demonstrated that the apoptotic 
Table II. Univariate Cox proportional regression analysis on the 5-year overall survival rate in patients with lower and middle rectal cancer.

\begin{tabular}{|c|c|c|c|}
\hline Characteristic & $\begin{array}{l}\text { Number } \\
\text { of cases }\end{array}$ & $\begin{array}{c}\text { 5-year } \\
\text { overall } \\
\text { survival, \% }\end{array}$ & P-value \\
\hline \multicolumn{4}{|l|}{ Gender } \\
\hline Male & 105 & 68.8 & \multirow[t]{2}{*}{0.762} \\
\hline Female & 75 & 62.5 & \\
\hline \multicolumn{4}{|l|}{ Age, years } \\
\hline$\leq 50$ & 66 & 70.0 & \multirow[t]{2}{*}{0.824} \\
\hline$>50$ & 104 & 65.0 & \\
\hline \multicolumn{4}{|l|}{ Blood transfusion } \\
\hline Yes & 116 & 67.5 & \multirow[t]{2}{*}{0.793} \\
\hline No & 64 & 61.9 & \\
\hline \multicolumn{4}{|l|}{ Course, months } \\
\hline$\leq 6$ & 116 & 65.8 & \multirow[t]{2}{*}{0.985} \\
\hline$>6$ & 64 & 63.9 & \\
\hline \multicolumn{4}{|l|}{ Tumor size, cm } \\
\hline$\leq 5$ & 93 & 66.3 & \multirow[t]{2}{*}{0.173} \\
\hline$>5$ & 87 & 58.8 & \\
\hline \multicolumn{4}{|l|}{ Pathology stage } \\
\hline Adenocarcinoma & 117 & 69.1 & \multirow[t]{3}{*}{0.041} \\
\hline Mucinous adenocarcinoma & & & \\
\hline Signet ring cell carcinoma & 63 & 59.0 & \\
\hline \multicolumn{4}{|l|}{ Depth of invasion } \\
\hline $\mathrm{T}_{1}+\mathrm{T}_{2}$ & 72 & 65.4 & \multirow[t]{2}{*}{0.032} \\
\hline $\mathrm{T}_{3}+\mathrm{T}_{4}$ & 108 & 53.9 & \\
\hline \multicolumn{4}{|l|}{ Lymph node metastasis } \\
\hline Yes & 114 & 66.5 & \multirow[t]{2}{*}{0.016} \\
\hline No & 76 & 49.2 & \\
\hline \multicolumn{4}{|l|}{ Livin expression } \\
\hline Negative & 96 & 45.0 & \multirow[t]{2}{*}{0.002} \\
\hline Positive & 84 & 68.0 & \\
\hline
\end{tabular}

rate of LoVo cells significantly increased compared with control groups $(\mathrm{P}<0.05$; Fig. 4).

Stable knockdown of livin expression decreases invasion capacity of LoVo cells. The Transwell invasion assay demonstrated that the invasion capacity was significantly reduced in stable livin knockdown cells as compared with control cells $(\mathrm{P}<0.05$; Fig. 5$)$.

Effect of knockdown of livin on LoVo cell chemosensitivity. The growth inhibition curves of L-OHP and 5-FU at six different concentrations were plotted in Fig. 6. It was demonstrated that knockdown of Livin by siRNA in LoVo cells resulted in much higher cell growth inhibition at different drug concentrations. The $\mathrm{IC}_{50}$ of L-OHP and 5-FU for the untransfected LoVo cells were 2.5, and $1.1 \mu \mathrm{M}$, respectively. However, the corresponding $\mathrm{IC}_{50}$ values dropped to 1.2 and $0.45 \mu \mathrm{M}$, respectively (both $\mathrm{P}<0.05$ ) when livin

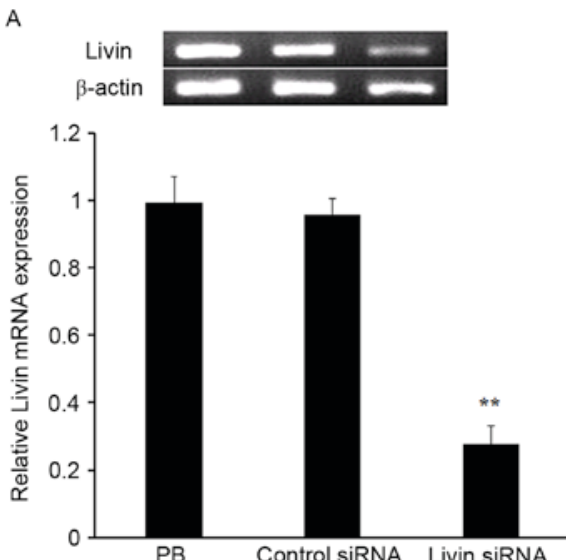

B

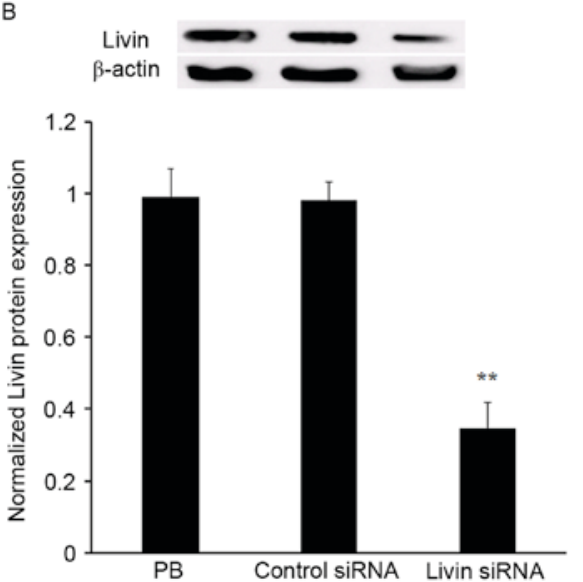

Figure 3. Specific downregulation of livin mRNA and protein expression by livin siRNA. LoVo cells were transfected with $100 \mathrm{nM}$ livin siRNA or scramble siRNA (control siRNA) for $48 \mathrm{~h}$. (A) The relative mRNA levels of livin were quantified by quantitative polymerase chain reaction analysis and (B) the relative protein levels of livin were determined by western blotting. Data were normalized by using $\beta$-actin as an internal standard. ${ }^{* *} \mathrm{P}<0.05$ vs. control siRNA. siRNA, small interfering RNA.

expression was knockdown by siRNA (Fig. 6), suggesting that a significant enhancement in chemosensitivity of L-OHP, and 5-FU LoVo cells compared with the untransfected cells or control siRNA-transfected cells.

\section{Discussion}

Mid-to-distal rectal cancer is prone to invade into adjacent tissues due to no peritoneum coat covering the mid-to-distal part of the rectum, and furthermore, the outcome of radical resection is affected by narrow pelvis or obesity in certain patients, therefore leading to poor prognosis $(24,25)$. Saito et al (26) reported that the 5-year survival rate following curative resection for local recurrence of rectal cancer in the asymptomatic group was significantly higher compared with that in the symptomatic group (62 vs. $23 \%$; $\mathrm{P}<0.05$ ). These findings suggested that timely treatment for local recurrence is associated with the prognosis of patients with rectal cancer. Local recurrence of rectal cancer occurs predominantly in the cavity and rarely in the anastomotic stoma, and anus examination, enteroscopy or barium enema are not applied following abdominoperineal excision. Despite the emergence of computed tomography, positron emission tomography and 
Table III. Multivariate Cox proportional regression analysis on the 5-year overall survival in patients with lower and middle rectal cancer.

\begin{tabular}{|c|c|c|c|c|}
\hline Characteristic & Partial regression coefficient & SE & OR & P-value \\
\hline Livin & 2.034 & 0.373 & 7.644 & 0.000 \\
\hline Lymph node metastasis & 1.649 & 0.342 & 5.203 & 0.000 \\
\hline
\end{tabular}

SE, standard error of the mean; OR, odds ratio.

A

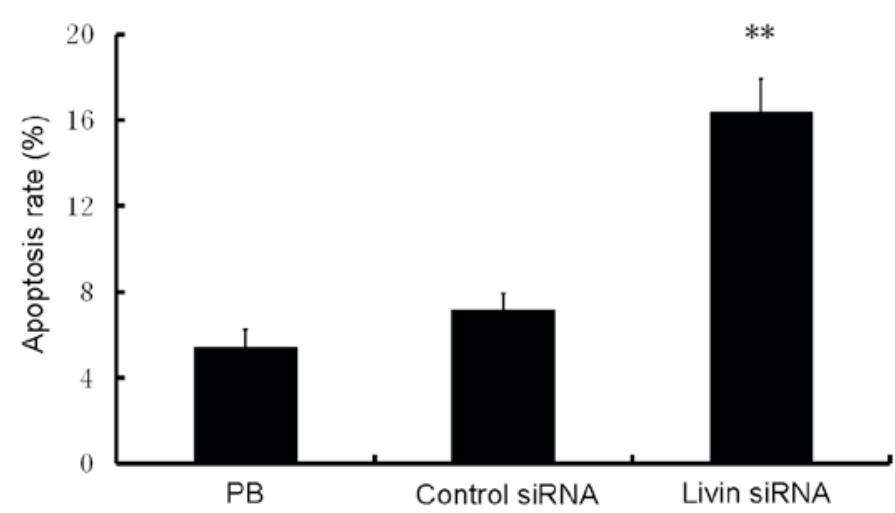

B
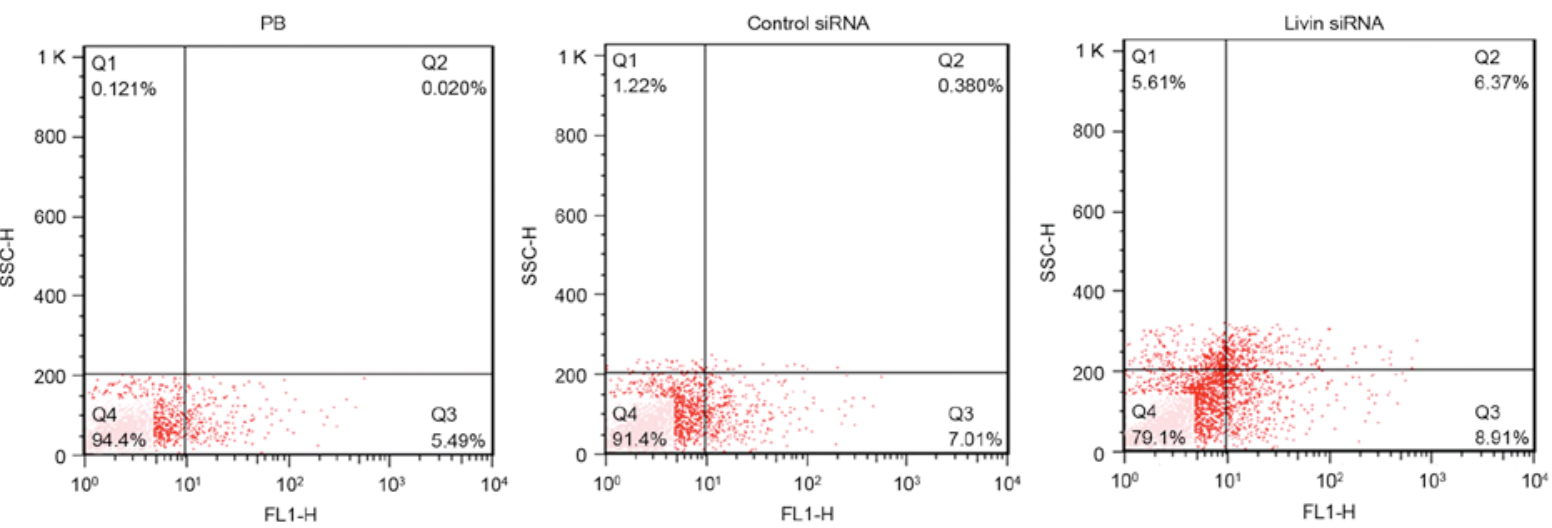

Figure 4. Analysis of cell apoptosis by flow cytometry assay. At $48 \mathrm{~h}$ post-transfection, apoptotic cells were determined by annexin V-positive and propidium iodide-negative cells. Livin siRNA induced apoptosis of LoVo cells. (A) The apoptosis rate of cells under the indicated conditions. Data are presented as the mean from three independent triplicate experiments. (B) Representative images of flow cytometry analysis of cell apoptosis. ${ }^{* *} \mathrm{P}<0.05$ vs. control siRNA. siRNA, small interfering RNA.

magnetic resonance imaging scans, the symptoms of pain, constipation, and bleeding are still considered the best predictors of signs of recurrence (27). However, for the majority of patients with rectal cancer, local recurrence is often diagnosed at late stage due to the high rate of asymptomatic patients (28). Therefore, diagnosis of recurrent rectal cancer is among the formidable challenges.

Various studies revealed that inhibited apoptosis contributes to the development and progression of cancer (7,29-31). Livin, an important member of the IAP family, was revealed to be expressed in multiple malignant tumors, and has been demonstrated to be essential for tumor progression and poor prognosis for several types of malignancies (12-16).
In the present study, it was revealed that the positive expression rate of livin was significantly higher in mid-to distal rectal cancer tissue compared with that in normal rectal mucosal tissues (53.3 vs. $6.67 \%$; $\mathrm{P}<0.05)$, indicating that the positive expression of livin is significantly associated with the oncogenesis of mid-distal rectal cancer. Pathological grade, extent of invasion ( $\mathrm{T}$ stage), extent of lymph node metastasis ( $\mathrm{N}$ stage) and livin expression $(\mathrm{P}<0.05$; Table II) were associated with 5-year survival rate.

Kanemitsu et al(32)reported thatmucinous adenocarcinoma itself was an independent prognostic factor in the curative resected patients. The extent of invasion ( $\mathrm{T}$ stage), extent of lymph node metastasis ( $\mathrm{N}$ stage) are included in the Dukes 

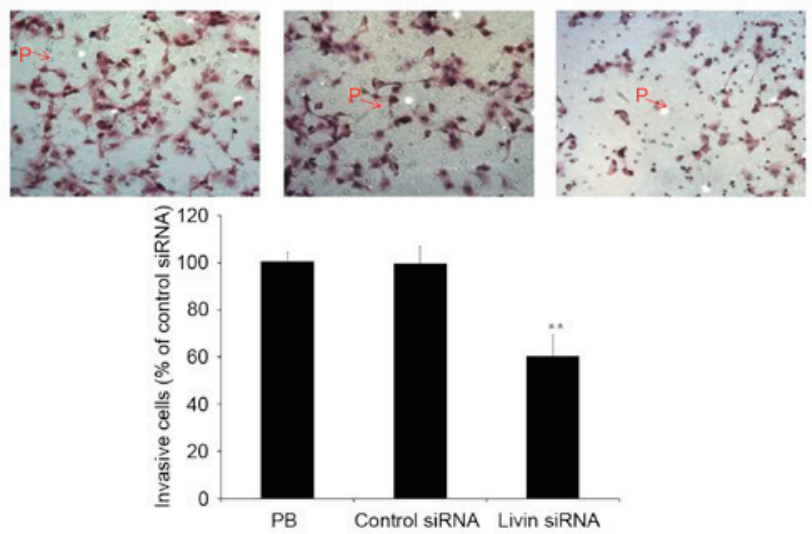

Figure 5. Stable-knockdown of livin suppressed LoVo cell invasion in vitro. The number of cells that had invaded the lower chamber was counted $24 \mathrm{~h}$ after seeding cells on the Transwells. ${ }^{* *} \mathrm{P}<0.05$ vs. control siRNA. siRNA, small interfering RNA.

classification, and are considered the independent prognostic factors in the majority of studies $(33,34)$. In the present study, the pathological grade and extent of invasion ( $\mathrm{T}$ stage) were excluded from the multivariate analysis model, suggesting that the other alternative factors in the model exhibit effects on the prognosis. As expected, multivariate Cox regression analysis revealed that livin expression and lymph node metastasis are two independent prognostic factors (both $\mathrm{P}<0.05$ ), of which livin expression is more important. It was also revealed that livin-knockdown by specific siRNA caused an increased apoptotic rate and decreased invasion capability of LoVo cells compared with the control group, indicating that livin depletion may lead to decreased recurrence of mid-to-distal rectal cancer.

It was proposed that aggressive surgery treatments should be applied for patients with mid-distal rectal cancer with positive livin expression. Holm et al (35) reported that cylindrical abdominoperineal resection was applied to treat patients with rectal cancer in T3-T4 stage. This technique creates a cylindrical specimen with more tissue covering and surrounding the tumor, providing the benefits of a low risk bowel perforation, and tumor involvement of the circumferential resection margin, thus leading to a potentially lower risk of local recurrence. The technique may be a novel surgery treatment for patients with mid-distal rectal cancer with positive livin expression, additional studies regarding its effect and benefits are warranted.

As is known, surgery is the basis of therapy for colorectal cancer (36), and the majority of patients with colorectal cancer receive chemotherapy to palliate advanced unresectable disease or to reduce the risk of recurrence following radical surgery, but efficacy must be carefully balanced against toxicity (4). In the present study, it was revealed that the $\mathrm{IC}_{50}$ of L-OHP and 5-FU dropped by $\sim 50 \%$ (both $\mathrm{P}<0.05$ ) in LoVo cells when livin expression was knocked down by siRNA, indicating a significant decrease in toxicity of L-OHP and 5-FU by siRNA.

In summary, in the present study, livin was identified to be highly expressed in mid-distal rectal cancer tissues compared with normal rectal mucosal tissues. Livin expression was associated with pathological grade, extent of invasion (T stage) and
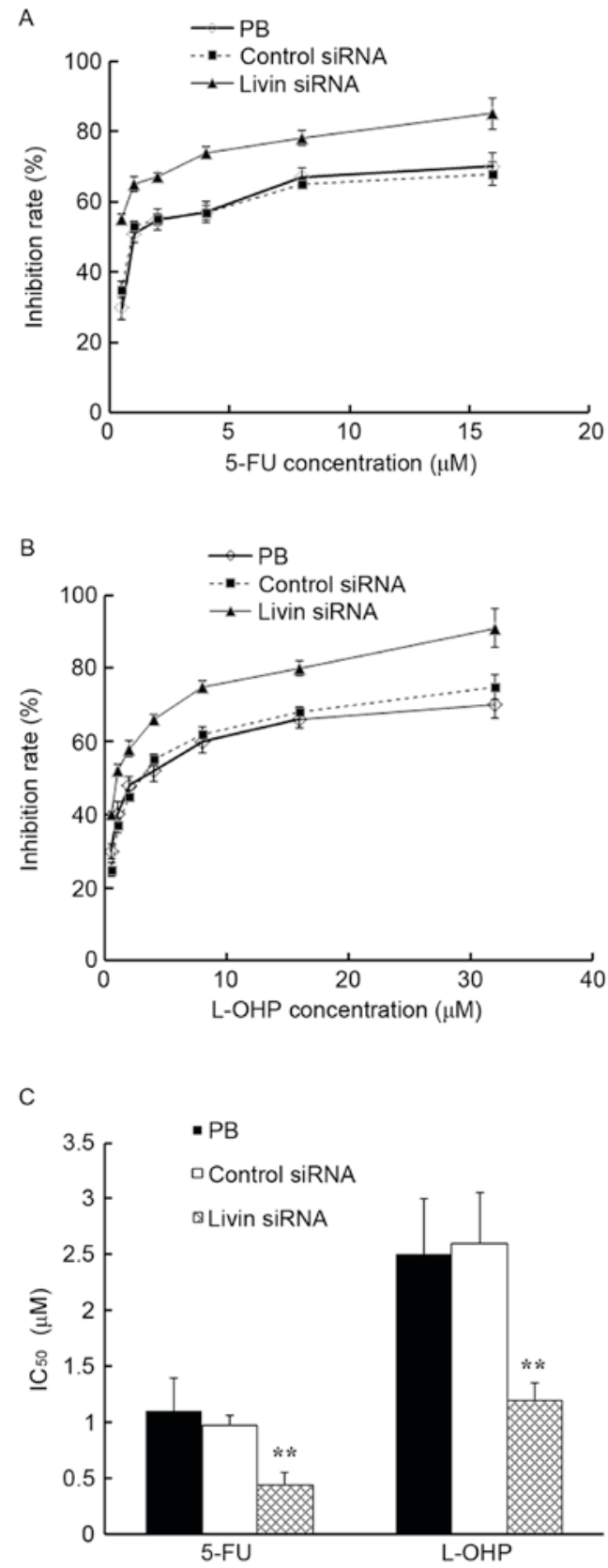

Figure 6. Live expression inhibition by siRNA potentiates effect of the 5-FU and L-OHP in vitro. Inhibition curves of (A) 5-FU and (B) L-OHP at different concentrations. (C) $\mathrm{IC}_{50} \mathrm{~s}$ of 5-FU and L-OHP to LoVo cells prior to, and following silencing livin inhibition. ${ }^{* *} \mathrm{P}<0.05$ vs. control siRNA. siRNA, small interfering RNA; 5-FU, 5- fluorouracil; L-OHP, oxaliplatin; $\mathrm{IC}_{50}$, half-maximal inhibitory concentration; $\mathrm{PB}$, phosphate buffered saline.

extent of lymph node metastasis ( $\mathrm{N}$ stage) of tumor, contributing to poor prognosis of mid-distal rectal cancer following surgery. The data suggested that aggressive surgery techniques should be applied in patients with mid-distal rectal cancer with high expression levels of livin. It was also revealed that $\mathrm{IC}_{50}$ of L-OHP and 5-FU dropped by $\sim 50 \%$ (both $\mathrm{P}<0.05$ ) in LoVo cells when livin expression was knocked down by siRNA. The data suggest that a combination of livin downregulation and anticancer drugs may significantly decrease the toxicity of anticancer drugs. The present study suggests that livin is a promising target for further study in the clinical therapy of mid-distal rectal cancer. 


\section{Acknowledgements}

The present study was supported by the Young and Middle-Aged Scientists Research Award Fund of Shandong Province of China (grant no. BS2010YY060) and Science and Technology Development Program of Shandong Province of China (grant. 2014GSF118134).

\section{References}

1. GLOBOCAN 2012: Estimated Cancer Incidence, Mortality and Prevalence Worldwide in 2012. IARC, Lyon, 2015. http://globocan.iarc.fr/Default.aspx. Accessed December 9, 2015.

2. Holmes D: A disease of growth. Nature 521: S2-S3, 2015.

3. Phipps AI, Limburg PJ, Baron JA, Burnett-Hartman AN, Weisenberger DJ,Laird PW, Sinicrope FA, Rosty C, Buchanan DD, Potter JD, et al: Association between molecular subtypes of colorectal cancer and patient survival. Gastroenterology 148: 77-87 e2, 2015.

4. Breugom AJ, Swets M, Bosset JF, Collette L, Sainato A, Cionini L, Glynne-Jones R, Counsell N, Bastiaannet E, van den Broek CB, et al: Adjuvant chemotherapy after preoperative (chemo) radiotherapy and surgery for patients with rectal cancer: A systematic review and meta-analysis of individual patient data. Lancet Oncol 16: 200-207, 2015.

5. Janzen DM, Tiourin E, Salehi JA, Paik DY, Lu J, Pellegrini M and Memarzadeh S: Corrigendum: An apoptosis-enhancing drug overcomes platinum resistance in a tumour-initiating subpopulation of ovarian cancer. Nat Commun 7: 10703, 2016.

6. Mullard A: Pioneering apoptosis-targeted cancer drug poised for FDA approval. Nat Rev Drug Discov 15: 147-149, 2016.

7. Bai L and Wang S: Targeting apoptosis pathways for new cancer therapeutics. Annu Rev Med 65: 139-155, 2014.

8. Fernald $\mathrm{K}$ and Kurokawa M: Evading apoptosis in cancer. Trends Cell Biol 23: 620-633, 2013.

9. Gyrd-Hansen M and Meier P: IAPs: From caspase inhibitors to modulators of NF-kappaB, inflammation and cancer. Nat Rev Cancer 10: 561-574, 2010.

10. Wang S, Bai L, Lu J, Liu L, Yang CY and Sun H: Targeting inhibitors of apoptosis proteins (IAPs) for new breast cancer therapeutics. J Mammary Gland Biol Neoplasia 17: 217-228, 2012.

11. Nachmias B, Ashhab Y and Ben-Yehuda D: The inhibitor of apoptosis protein family (IAPs): An emerging therapeutic target in cancer. Semin Cancer Biol 14: 231-243, 2004.

12. Chung CY, Park YL, Kim N, Park HC, Park HB, Myung DS, Kim JS, Cho SB, Lee WS and Joo YE: Expression and prognostic significance of Livin in gastric cancer. Oncol Rep 30: 2520-2528, 2013.

13. Ibrahim L, Aladle D, Mansour A, Hammad A, Al Wakeel AA and Abd El-Hameed SA: Expression and prognostic significance of livin/BIRC7 in childhood acute lymphoblastic leukemia. Med Oncol 31: 941, 2014.

14. Li F, Yin X, Luo X, Li HY, Su X, Wang XY, Chen L, Zheng $\mathrm{K}$ and Ren GS: Livin promotes progression of breast cancer through induction of epithelial-mesenchymal transition and activation of AKT signaling. Cell Signal 25: 1413-1422, 2013.

15. Lin X, Li HR, Lin XF, Yu ME, Tu XW, Hua ZD, Lin M, Xu NL, Han LL and Chen YS: Silencing of Livin inhibits tumorigenesis and metastasis via VEGF and MMPs pathway in lung cancer. Int J Oncol 47: 657-667, 2015.

16. Xi RC, Sheng YR, Chen WH, Sheng L, Gang JJ, Tong Z, Shan Z, Ying GH and Dong LC: Expression of survivin and livin predicts early recurrence in non-muscle invasive bladder cancer. J Surg Oncol 107: 550-554, 2013.
17. Myung DS, Park YL, Chung CY, Park HC, Kim JS, Cho SB, Lee WS, Lee KH, Lee JH and Joo YE: Expression of Livin in colorectal cancer and its relationship to tumor cell behavior and prognosis. PLoS One 8: e73262, 2013.

18. Xi RC, Biao WS and Gang ZZ: Significant elevation of survivin and livin expression in human colorectal cancer: Inverse correlation between expression and overall survival. Onkologie 34: 428-432, 2011

19. Associatioon TCoCCoCa-c: Guidelines for surgery of mid and distal rectal cancer. Chin J Gastrointest Surg 10: 1-7, 2007.

20. Bosman FT, Carneiro F, Hruban RH and Theise ND: WHO Classification of Tumours of the Digestive System, Fourth Edition. IARC Press, Lyon, 2010.

21. International Union against Cancer: TNM classification of malignant tumours. Sobin LH, Gospodarowicz MK and Wittekind C (eds). Wiley-Blackwell, Chichester, West Sussex, UK; Hoboken, NJ, USA, 2010.

22. Yuan B, Ran B, Wang S, Liu Z, Zheng Z and Chen H: siRNA directed against Livin inhibits tumor growth and induces apoptosis in human glioma cells. J Neurooncol 107: 81-87, 2012.

23. Schmittgen TD and Livak KJ: Analyzing real-time PCR data by the comparative C(T) method. Nat Protoc 3: 1101-1108, 2008.

24. Stewart CJ, Hillery S, Platell C and Puppa G: Assessment of serosal invasion and criteria for the classification of pathological (p) T4 staging in colorectal carcinoma: Confusions, controversies and criticisms. Cancers (Basel) 3: 164-181, 2011.

25. Wang H, Wei XZ, Fu CG, Zhao RH and Cao FA: Patterns of lymph node metastasis are different in colon and rectal carcinomas. World J Gastroenterol 16: 5375-5379, 2010.

26. Saito N, Koda K, Takiguchi N, Oda K, Ono M, Sugito M, Kawashima $\mathrm{K}$ and Ito M: Curative surgery for local pelvic recurrence of rectal cancer. Dig Surg 20: 192-199; discussion 200, 2003.

27. Hellinger MD and Santiago CA: Reoperation for recurrent colorectal cancer. Clin Colon Rectal Surg 19: 228-236, 2006.

28. Pereira P, Ghouti L and Blanche J: Surgical treatment of extraluminal pelvic recurrence from rectal cancer: Oncological management and resection techniques. J Visc Surg 150: 97-107, 2013.

29. Byun DS, Cho K, Ryu BK, Lee MG, Kang MJ, Kim HR and Chi SG: Hypermethylation of XIAP-associated factor 1, a putative tumor suppressor gene from the 17p13.2 locus, in human gastric adenocarcinomas. Cancer Res 63: 7068-7075, 2003.

30. Cao J, Chen XP, Li WL, Xia J, Du H, Tang WB, Wang H, Chen XW, Xiao HQ and Li YY: Decreased fragile histidine triad expression in colorectal cancer and its association with apoptosis inhibition. World J Gastroenterol 13: 1018-1026, 2007.

31. Mesri M, Wall NR, Li J, Kim RW and Altieri DC: Cancer gene therapy using a survivin mutant adenovirus. J Clin Invest 108: 981-990, 2001 .

32. Kanemitsu Y, Kato T, Hirai T, Yasui K, Morimoto T, Shimizu Y, Kodera Y and Yamamura Y: Survival after curative resection for mucinous adenocarcinoma of the colorectum. Dis Colon Rectum 46: 160-167, 2003.

33. Sternberg A, Sibirsky O, Cohen D, Blumenson LE and Petrelli NJ: Validation of a new classification system for curatively resected colorectal adenocarcinoma. Cancer 86: 782-792, 1999.

34. Tsai HL, Lu CY, Hsieh JS, Wu DC, Jan CM, Chai CY, Chu KS, Chan HM and Wang JY: The prognostic significance of total lymph node harvest in patients with T2-4N0M0 colorectal cancer. J Gastrointest Surg 11: 660-665, 2007.

35. Holm T, Ljung A, Haggmark T, Jurell G and Lagergren J: Extended abdominoperineal resection with gluteus maximus flap reconstruction of the pelvic floor for rectal cancer. Br J Surg 94: 232-238, 2007

36. Cunningham D, Atkin W, Lenz HJ, Lynch HT, Minsky B, Nordlinger B and Starling N: Colorectal cancer. Lancet 375: 1030-1047, 2010. 